\title{
РАЗДЕЛУІІІ. ЮРИСПРУДЕНЦИЯ
}

\author{
Brisov Y.V. \\ How the courts exorcise demons from legal body or a new standard for a bona fide \\ purchaser in Russia
}

Russian State University of Justice

(Russia, Moscow)

doi $10.18411 /$ scc-09-2018-23

idsp 000001:scc-09-2018-23

\section{Dispute Background}

The real property law is as old as the law itself. The transactions of real property are the most common types of deals all over the world. However, after the contract has been signed and the money have been paid it is not always clear if the title for the property have been transferred to a new owner or not. In such cases the issue of a bona fide purchaser usually arises before the court. We will see that sometimes these issues are far from ordinary, and still they took place and a considerable number of hours and legal effort to be solved. In this article we will address to nontrivial cases dedicated to unveiling the legal approaches to the bona fide purchaser of real property doctrine by Civil law and Common law judges.

We will also immerse in the history of the establishment and the development of the Roman law principle of Bona fides, it's transformations through time in a form of the standard of good faith and fair dealing on one hand and a strict principle of Caveat Emptor that is still applicable in the Common Law countries but very rarely addressed in Civil Law countries. We will father see how the doctrine of good faith was adopted by Russian Civil Law, the difficulties of the codification and application of a new doctrine after the era of strict law of the Soviet Union.

\section{Diem clausit extremum}

The first case we would like to discuss took place in Russia and has been solved by The Constitutional Court or Russian Federation. A bona fide purchaser acquired an apartment under a sale and purchase transaction. Subsequently, it was found that the transferors of the property had made a number of bad faith transactions to cover the fact that the apartment was an heirless property (it was not transmitted to an individual or a legal entity after the owner's death) and, consequently, was to be escheated by the Russian Federation according to Russian property law. The swindlers.made use of certain sluggishness of public establishment and declaration of rights to escheated property, made several masking transactions and sold the property with a "clear" title to a person who did not suspect a thing. Unfortunately, such shenanigans were not infrequent and each bona fide purchaser was exposed to the risk of vindication before The Constitutional Court of Russian Federation put an end to it just last summer and overruled Clause 1 of Article 302 of Russian Civil Code.

Indeed, Clause 1, Article 302 Civil Code of Russian Federation (hereinafter - GK RF) reads as follows:

If property was acquired for a consideration from a person who did not have the right to alienate it, of which the purchaser did not know and could not have known (a bona fide purchaser), the owner has the right to recover the property from the purchaser in the case where the property was lost by the owner or by a person. - 
Such a standard for a bona fide purchaser worked in favor of swindlers and resulted in challenging a vast number of transactions with immovable property. The Supreme Commercial Court and the RF Supreme Court tried to clarify the issue.

Thus, Clause 38 of Ruling of the Plenum No. 10/22 establishes that the respondent may be recognized a bona fide purchaser of property if the transaction under which he acquired possession of a challenged property has the features of a valid transaction in all respects except that it was made by an unauthorized transferor.

However, such clarifications also contained some ambiguous wordings. For example: "[A bona fide purchaser] must have doubted the seller's right to convey the property;" he could not be considered a bona fide purchaser. Unfortunately, nobody explained what the term "doubted" specifically meant. Russian lawyers who provided due diligence for property transactions joked that a bona fide "doubt about the seller's right" to convey property meant: (1) to verify the three last transfers of title of property; (2) to enter the apartment or the house, to look into cupboards and closets; and (3) to have a chat with "babushkas" (elderly women in Russia) who usually sat on a bench at the entry.

Confusion was aggravated even more by the fact that a unified register of the rights to immovable property is maintained in the Russian Federation (USRP (the Unified State Register of Immovable Property) from 2017, formerly known as USRR (the Unified State Register of Rights). In addition, Ownership Certificates in a government-approved format were issued to immovable property owners until 2017, protected by watermarks and special symbols. As early as the beginning of 2017, it grew clear that the legislator's intention was to put an end to schemes in the real property market by cancelling Ownership Certificates.

The reason for the reform was making the process of registration of rights to immovable property more transparent and declaring the principle of public register reliability in a special law 218-FZ and Article 8.1 of the GK RF.

Following the legislative trend, The Constitutional Court overruled an exception from the bona fide principle in form of delayed public interest, which, like a ghost remained behind the scenes to each transaction with the immovable property until the expiry of a prolonged limitation period. Otherwise, how could a bona fide purchaser rely on the registration system if the information provided by the Unified State Register of Immovable Property does not cover all the aspects of a title?

If only some aspects can be unveiled and some are tended to be hidden from any reasonable inspection or due diligence, how can a real estate market work properly? The discussed Ruling of The Russian Constitutional Court carved into the stone of Russian property law that the individual who is the ultimate purchaser of housing in a chain of transactions shall not be held liable for the state's omissions and shall be protected as the owner if he has paid a reasonable price for the acquired apartment.

\section{The Ghosts of Common Law legal system}

In Common Law, the issues of the bona fide purchaser also arise quite frequently. The American Courts have to deal with their legal ghosts inherited from the historical development of the Common Law legal system. The Roman doctrine that governs the property purchase contracts in Common Law countries is called Caveat Emptor (let the buyer beware). Developed in England at the times of Magna Carta this principle means, that in most instances, the buyer must inspect and discover any conditions. Prima facie this approach does not strike as a completely different from what we have discussed above, analyzing the case of The Russian Constitutional Court. Nevertheless, there are some core differences.

The buyer can ask the seller for warranties as to general conditions or suspicions found after a reasonable inspection of the property. Shall the seller decide to give such warranties and lie he will be liable for damages, but if no warranties were provided, the mere silence of the seller does not give the buyer the right to rescind the contract. In Civil Law countries the implied requirement of good faith will generally leave the chance to rescind the contract by the duty of good faith and fair dealing. This principle is quite complicated, and sometimes it 
may contradict with the buyer's fair expectation of profit, which the modern economy is built upon.

However, even a Common Law rule seeming so perfectly balanced through over the centuries may face the exception. In Stambovsky v. Ackley The plaintiff bought a house reported to be possessed by poltergeists. This information was evident to the defendant and members of his family. He even opens the house for tours, but the plaintiff was not from that village, he was a resident of New York City, he was neither familiar with the village nor with its legends and myths. Plaintiff enters into a contract to purchase the house with the good faith desire to live there with his family with no roommates however mistrial the may have been.

Before the closing Plaintiff discovered that the house was haunted and wants to rescind. The Court has to decide whether the buyer can rescind a land sale contract by failure to disclose a material condition. The Court concluded, "Common law is not moribund. Ex facto jus oritur (law arises out of facts). Where fairness and common-sense dictate that an exception should be created, the evolution of the law should not be stifled by rigid application of a legal maxim." The Court held that where a condition has been created by the seller materially impairs the value of the contract and is within the knowledge of the seller or unlikely to be discovered by a prudent purchaser exercising due care for "the subject transaction, nondisclosure constitutes a basis for rescission as a matter of equity."

\section{Bona Fides Principle in historical development of Civil Law}

A key issue discussed by the parties in the above cases is the approach established in practice to prove a bona fide purchaser. The aggrieved parties in both cases applied to the doctrine of good faith. Though the two courts came to the resembling conclusions, they had the different starting points. The American Court set another explanatory exception to the Caveat Emptor principle. The Russian Court had to deal with the complex set of principles, which composed the modern European understanding of a bona fide purchaser. The heated dispute has arisen among Russian scholars and practicing lawyers as to the issue of a standard of good faith.

The Russian Constitutional Court relies on its position on the practice of European courts, which may be reduced to an unambiguous position as follows: "the purchaser of housing shall not assume the risk related to defects that must be removed by the state itself." It was not in an instant that the civil law tradition came to the current understanding. The Roman Law allowed for the seizure of property from a bona fide purchaser by way of a vindicatory action. "The possibility of vindication as such and consistent implementation thereof gave rise to general uncertainty of civil law transactions since a purchaser never might be sure that he became the owner. The possibility always existed that a person would appear who would prove his ownership of the thing and take it away."

In the German common law, the principle of "Hand muss Hand wahren" existed with respect to transactions with movable property; that is, only the things that went away from the owner's hands against his will (stolen or lost) were to be seized and returned to the former owner. The things that were voluntarily entrusted to anybody and alienated thereby left the owner conclusively and any bona fide purchaser thereof became the immutable owner, whereas the former owner had the right to a claim for damages against those to whom the things were entrusted.

An actual protection of a bona fide purchaser began with the establishment of the bona fide principle in civil codes of European states. In Germany, bona fides could conveniently be blended with the indigenous notion of Treu und Glauben (literally: fidelity and faith): "a phrase which we find in a number of medieval sources and which was used, in the context of commercial relations, as a synonym for bona fides." Treu und Glauben also, of course, was ultimately destined to find its way into the famous $\S 242$ of the German Civil Code of 1900: "Der Schuldner ist verpflichtet, die Leistung so zu bewirken, wie Treu und Glauben mit Rücksicht auf die Verkehrssitte es erfordern." This is not the only place where the BGB refers 
to Treu und Glauben; for according to $\S 157$ BGB 'contracts shall be interpreted according to the requirements of good faith; ordinary usage being taken into consideration.

However, in addition to the bona fide principle as an objective principle oin civil law, bona fide also exists as a certain "subjective standard" where a "Guter Glaube" (Bona Fide) purchaser is meant, similarly to a bona fide purchaser in common law. It is not a vague legal principal but a number of standard characteristics that Courts use to test a deal for an element of bona fide in it.

The Russian pre-revolutionary legal doctrine also knew the bona fide principle. Keeping pace with their foreign colleagues, Russian authors elaborated the subjective and objective Good Faith standards concerning civil law in the Tsar Empire. Unfortunately, theoretical works of Russian civil law scholars were to gather dust on shelves for a long period of time. In the Soviet Union, Russian law was dominated by strict law, ius strictum, which significantly impeded perception by contemporary Russian legal system the understanding of open rules, in particular, the bona fide principle, introduced by the legislator in the course of a large-scale civil law reform. Famous Russian scholar of the New wave law A.M. Shirvindt points out that "an attempt to put the courts at ease by way of the formal establishment of the bona fides (good faith) principle in the RF Civil Code is conceived in the absence of even a rough idea of the current state of affairs."

Now we will witness some of the difficulties that the Russian judges had to face. One of the reasons was bared in the text of Russian Civil Code, and for the judges raised in a tradition of governing textualism, it was a severe challenge to work with the reformed Civil Code. The discussed above subjective standard of good faith is clarified by the legislator Russian Civil Code.

For example, in Clause 2, Article 174.1 of GK RF:

A transaction made in violation of the prohibition from disposition of the debtor's property, imposed in a judicial proceeding or in any other way determined by law, shall not prevent from exercising the rights of such creditor or authorized person, secured by the prohibition, except for the cases where the purchaser of the property did not know and should not have known of the prohibition.

See also Clause 1, Article 901 of GK RF Grounds for the Bailee's Liability:

The bailee shall be liable for loss or shortage of or damage to a thing received for bailment unless he proves that the loss, shortage or damage occurred as a result of force majeure or due to the qualities of the thing of which the bailee did not know and should not have known when receiving the thing into bailment, or as a result of intent or gross negligence of the bailor.

We can also see that subjective standard of good faith is put in different words in Clause 1, Article 302 of GK RF, "If a property was acquired for a consideration from a person who did not have the right to alienate it, of which the purchaser did not know and could not have known (a bona fide purchaser)." Here, we see a different wording, did not know and could not have known, but we should understand in the context that it is also meant did not know and should not have known. Despite almost identity of the grammatical structures, in the law application context the wording "could not have known" protects a bona fide party to legal relationships to a considerably lesser extent.

If we consider bona fide regarding probabilities ("could"), the boundary of which is not determined by law, bona fide loses its status of a subjective standard and may only be applied categorically like Treu und Glauben or Good faith and fair dealing vague legal doctrine. Such kind of application of bona fide in disputes is not only inconsistent with the established ius strictum understanding of the law but with common sense as well. The above issue of "could not" and "should not" was not discussed by the Constitutional Court in the 
case we are referring to in the article. This issue shreds the light on the legal understanding of bona fides principal in general and on a status of the bona fide purchaser within the Russian judicial system.

Before the very recent developments, including those, that the Court made in the discussed case, there was a strong understanding among Russian juridical society - a mere physical possibility to determine the potentially lousy condition was enough to erase the bona fide purchaser protection in real estate deals. This approach laid a terrible burden of suspicion and ambivalence on the market of real property and prevented it from evolving naturally for quite an extended period.

\section{Conclusion}

Why have compared two cases that may seem to be quite different. The reason for the choice of case law was a "Who you gonna call" factor that in our opinion consolidate the cases, something unpredictable and unforeseeable that was discovered in both cases and brought two different courts operating by two different systems of law to the resembling conclusions. The Appellate Division Court of New York on June the 18th, 1991 set the important rule that generally applies to caveat emptor since then, "The notion that a haunting is a condition that can and should be ascertained upon reasonable inspection of the premises is a hobgoblin which should be exorcised from the body of legal precedent and laid quietly to rest."

Moreover, The Constitutional Court or Russian Federation in June 22, 2017 - almost precisely in 16 years - which is also ironically mysterious enough, comes to the very same conclusion that a purchaser, who was not able to establish a certain condition during the reasonable inspection of property cannot be tide by this condition to any obligation. We find both decisions to be fair and just. No matter what historical or legal background or Legal System the Court belongs to it should curtail the bogus understanding of law and exorcise hobgoblins from the legal body because that law should provide the conditions for a lasting and effective turnover not to prevent them.

$$
* * *
$$

1. Alistarkhov V. Istrebovaniye zhilih pomesheniy ot dobrosovestnyh priobretateley. Noviy obzor sudebnoy praktiki [Vindication of immovable proprety. Overview of court decisions]// «Zhilishnoe Pravo». 2015. N1 pp. 77-81

2. Postanovlenie Konstutsionnogo Suda N 16-P, Quoting Judgment of the European Court of Human Rights of Dec. 06, 2011 in the case of Gladysheva v. Russia (application No. 7097/10) and of Jan. 29, 2015 on the case Stolyarova v. Russia (application No. 15711/13)

3. Postanovlenie Konstutsionnogo Suda RF ot 22 iunia № 16-P 2017 g. [Ruling of the Russian Federation Constitutional Court of Jun. 22, 2017], Rossiisaia Gazeta [ros. Gaz.] Jul. 4, 2017, No 7310, Item 144

4. Postanovlenie Plenuma Verkhovnogo Suda RF №. 10, Plenuma VAS RF No. 22 ot 29 aprelia 2010 (red. ot 23 iunia 2015) [Ruling of the Plenum of the RF Supreme Court No. 10, the Plenum of the RF SCC No. 22 of Apr. 29, 2010 (in the version of Jun. 23. 2015)] "O nekotorykh voprosakh, voznikayushchikh v sudebnoy praktike pri razreshenii sporov, svyazannykh s zashchitoy prava sobstvennosti i drugikh veshchnykh prav" [On Certain Issues Arising in the Court Practice at Settlement of Disputes Related to Protection of Right of Ownership and Other Rights in Rem]

5. Stambovsky v. Ackley, 169 A.D.2d 254, 258 (N.Y. App. Div. 1st Dept. 1991)

6. Civil Code of the Russian Federation (Part One) of Nov. 30, 1994, No. 51-FZ (in the version of Jul. 29, 2017) (as amended, effective from Aug. 2017) https://login.consultant.ru/link/?req=doc\&base=ROS\&n=220995\&div=LAW\&dst=101514\%2C0\&rnd=0.7 927574271132031 (last visited Oct. 31, 2017)

7. Federal Law of July 13, 2015 No. 218-FZ (in the version of Jul.29, 2017) On State Registration of Immovable Property (as amended, effective from Aug. 11, 2017) Official Internet portal of legal information http://www.pravo.gov.ru.

8. Bevzenko R. Dobrosovesniy priobretatel' kvartiry. Standart dobrosovesnosti. [Bona fied purchaser of an apartment. Standard of good faith] available https://zakon.ru/blog/2014/10/13/dobrosovestnyj_priobretatel_kvartiry_standart_dobrosovestnosti (last visited Nov. 23, 2017) 
9. Pokrovskiy I.A., Osnovnye problem grazhdanskogo prava [Main Problems of Civil Law], 3rd ed., stereotype, "Statut", 2001, 328 p.

10. Molot J.T. Columbia Law Review Vol. 106, No. 1 (Jan., 2006), pp. 1-69

11. Shirvindt A.M., Printsip dobrosovestnosti v GK RF i sravnitelnoye pravovedenie [Bona Fide Principle in the RF Civil Code and Comparative Law], Statut, M., 2014, pp. 203-242

12. Zimmermann R., Whittaker S., Good Faith in European Contract Law, Cambridge University Press, 2000, $756 \mathrm{p}$.

13. Ballentine's Law dictionary Copyright (c) 2010 LexisNexis ${ }^{\circledR}$, a division of Reed Elsevier, plc.

14. history.com. (2015). Magna Carta - British History - HISTORY.com. [online] Available at: http://www.history.com/topics/british-history/magna-carta (last visited Nov. 03, 2017)

\section{Пролетенкова С.Е. ${ }^{1}$., Быков Б.А. ${ }^{2}$ \\ Ведомственная оценка эффективности деятельности подразделений ОВД по противодействию коррупции и обеспечению экономической безопасности}

${ }^{1}$ Всероссийский Научно-исследовательский институт МВД России» ${ }^{2}$ Академия права и управления МВД России

doi $10.18411 /$ scc-09-2018-24

idsp 000001:scc-09-2018-24

\section{Аннотация}

В статье рассмотрены положения Приказа МВД России № 1040, которые, не позволяют в настоящее время использовать систему оценки таким образом, чтобы она позволяла получить реальные измеримые результаты деятельности органов внутренних дел в сфере обеспечения экономической безопасности и противодействия коррупции, а также способствовала отходу от так называемой «палочной системы». Внесены конкретные предложения по оптимизации системы оценки.

Ключевые слова: противодействие коррупции, оценка эффективности, органы внутренних дел, экономическая безопасность, ЭБиПК, показатели.

Необходимо отметить, что текстуальная попытка объединить в рамках оценки результаты деятельности отдельных подразделений полиции представляется не слишком удачной. Фактически для каждой службы, в том числе ЭБиПК, критериев оценки слишком мало, что не позволяет отражать реальную картину деятельности. Например, исходя из перечисленных показателей, нет разницы в том, сколько эпизодов преступной деятельности в экономической сфере совершила организованная преступная группа или члены преступного сообщества, принимается во внимание только количество лиц, направленных в суд. При этом объем правоохранительной деятельности выполняемый сотрудниками подразделений ОЭБиПК существенно различается относительно количества «эпизодов». Для иных служб в Приказе предусмотрен только один (например, для экспертно-криминалистических подразделений) или несколько показателей. Определенным образом ситуацию исправляет наличие дополнительных методик оценки эффективности деятельности отдельных служб органов внутренних дел, утвержденных приказами имеющими гриф «для служебного пользования». Подобная детализация показателей предусмотрена и для подразделений ЭБиПК. Вместе с тем, наличие подобной двухфазной методики оценки с несовпадающими показателями порождает свои сложности. Если, как мы уже отмечали, по п.п. 1.4, 1.5 Приказа № 1040 учитывается «количество лиц», то в соответствии с конкретизированной методикой для подразделений ЭБиПК учитывается «количество выявленных преступлений», что порождает ситуацию, когда по одному приказу подразделение может показать высокий результат, а по другому нормативному акту - обратный. Количественные показатели выявленных преступлений, в свою очередь «вынуждают сотрудников больше уделять внимание не сложным схемам, а 